Univerzitet u Beogradu
Poljoprivredni fakultet
Institut za poljoprivrednu tehniku
Naučni časopis
POLJOPRIVREDNA TEHNIKA
Godina XLVI
Broj 4., 2021.
Strane: $1-9$

\title{
THE USE OF SOLAR PLANTS FOR CROP SEEDS DRYING
}

\author{
Aleksey Kupreenko ${ }^{1}$, Khafiz Isaev ${ }^{1}$, Yury Kuznetsov*2, Stanislav Mikhailichenko', \\ Igor Kravchenko ${ }^{3}$, Larisa Kalashnikova ${ }^{4}$ \\ ${ }^{1}$ Bryansk State Agrarian University, Bryansk, Russia \\ ${ }^{2}$ Orel State Agrarian University, Orel, Russia \\ ${ }^{3}$ Russian State Agrarian University -Moscow Timiryazev Agricultural \\ Academy, Moscow, Russia \\ ${ }^{4}$ Orel State University, Orel, Russia
}

\begin{abstract}
A grain drying complex based on solar energy, including a grain storage with a built-in solar drying system and a drum solar dryer for grain, is proposed. The construction and principle of operation of the grain drying complex is described. The basis of each of the solar drying systems of the complex is the presence of two solar collectors, one of which provides heating of the drying agent at the inlet into the drying chamber, and the second - heating of the used drying agent in the exhaust pipe to increase its flow rate and, accordingly, the intensification of grain drying. Availability of gravel or water heat accumulators allows to carry out the process of grain drying or grain storage, at night and under adverse weather conditions without the risk of self-heating. The optimum capacity of the gravel accumulator is $0.5-0.75 \mathrm{~m}^{3}$ per $1 \mathrm{~m}^{2}$ of solar collector area. Drum solar dryer provides guaranteed drying of a grain batch for 6-7 hours of the day time and a grain batch for the night time. It was found that the optimum thickness of the grain layer in the drying process is $50-70 \mathrm{~cm}$ and specific load is up to $100 \mathrm{~kg}$ of grain per square meter of the horizontal solar collector area.
\end{abstract}

Key words: Solar plant, moisture, solar dryer, drying chamber, air exchange, grain storage

\footnotetext{
*Corresponding Author. E-mail: kentury@yandex.ru
} 


\section{INTRODUCTION}

Drying is an important, but very energy-consuming technological process of postharvest processing of agricultural crops seeds. For example, for final grain drying various types of dryers with the average flow of liquid fuel up to $100 \mathrm{~kg} / \mathrm{h}$ or gas $70 \mathrm{~kg} / \mathrm{t}$ and the preset capacity of electric motors about $50 \mathrm{~kW}$ are used. When using existing installations, grain drying accounts for 85 to $97 \%$ of the total energy consumption for its processing [1]

With small production volumes of grain seeds and vegetable crops the use of high-temperature dryers is not economically justified. The use of simple floor dryers with electric air heating requires large amounts of electricity and manual labor.

To reduce energy costs, solar plants are most often proposed [2-8]. They are simple in design and can be used as independent drying units and for preheating the drying agent in high-temperature dryers.

Due to the large variety of solar plant designs, research is needed to determine the optimal technological schemes of solar dryers for agricultural crops seeds [9-11].

\section{MATERIAL AND METHODS}

To combine the technological operations of energy-saving drying and grain crops storage a prototype grain drying complex based on an alternative energy source was created and tested. It includes a section of a grainery with built-in solar drying system (fig. 1) and a drum-type grain solar dryer (fig. 2).

Solar dryer-grain storage has (fig. 1) a vertical solar collector 1 with a translucent cover 2 and light-absorbing surface 3, drying chamber 4 with a perforated deck 5 for placing on it dried grain 6, and exhaust pipe 7 also in the form of a solar collector with deflector 8. Gravel accumulator 9 is placed under the decking 5. The perforated airdistribution channels 10 are on the decking 5. Their quantity and height are chosen in such a way that the distance between them and from the top of the channel to the surface of the dried material was about the same. This ensures the passage of the drying agent through the entire thickness of the grain (optimally from 50 to $70 \mathrm{~cm}$ ). Under-deck space is connected with the vertical solar collector 1 by means of openings 11 in the wall of the grain storage [12].

Division of the drying chamber and the floor space into compartments for drying, for example, different varieties or types of crops by longitudinal 12 and transverse 13 partitions. Along the compartments a technological corridor runs, at the ends of which the gate 14 is located. Air exchange regulation in the grain storage is done by means of shutters 15. In order to reduce sailing, exhaust pipe 7 with a height sufficient to overcome the hydraulic resistance of the grain layer and reverse thrust in the solar collector (optimally - one and a half times the height of the solar collector 1), is made in separate sections. Entrance slot in the upper part of the solar collector 1 is covered with a grid from insects and rainfall canopy 16 of the roof. The walls, roof and gates of the grain storage must be thermally insulated and sealed so that there is no air suction, bypassing the solar collector 1 . 

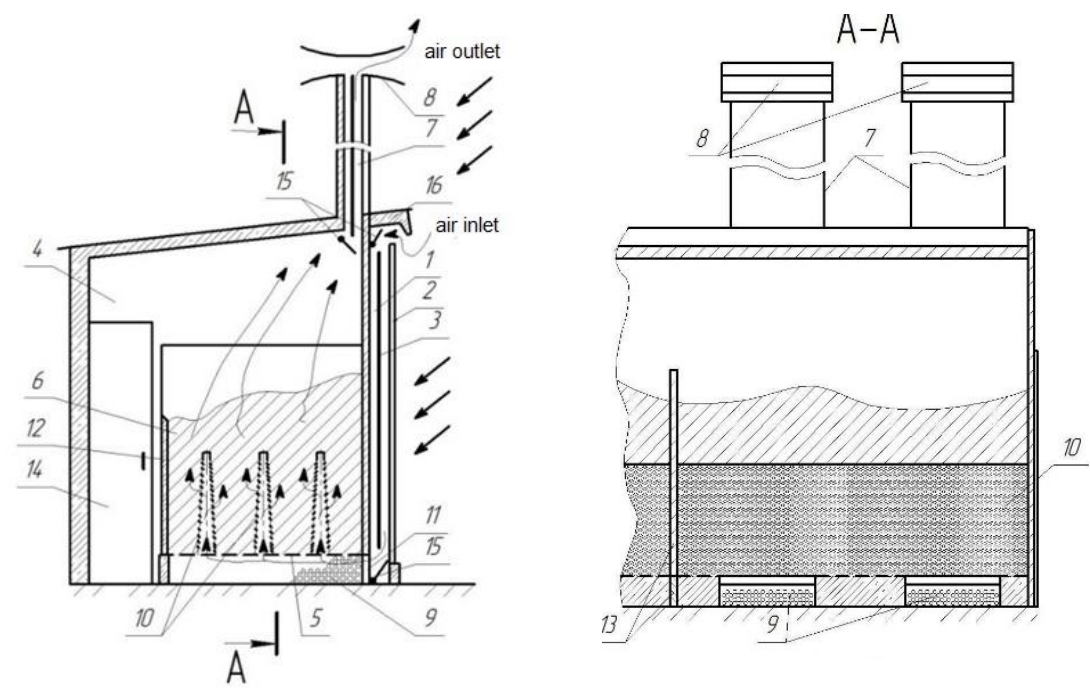

a)

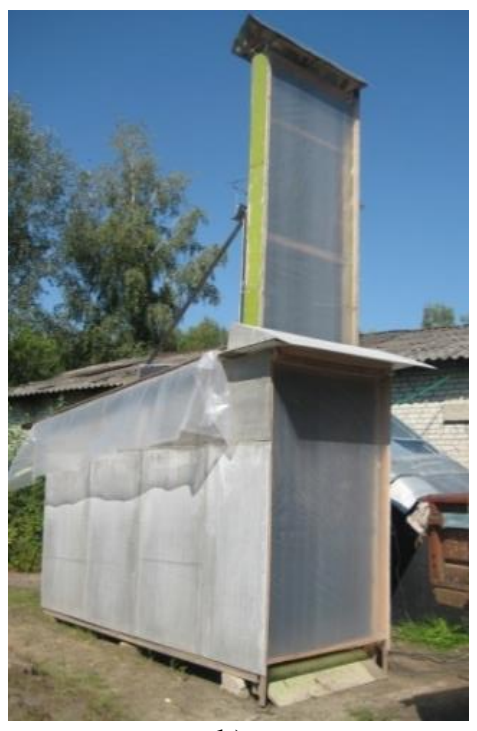

b)

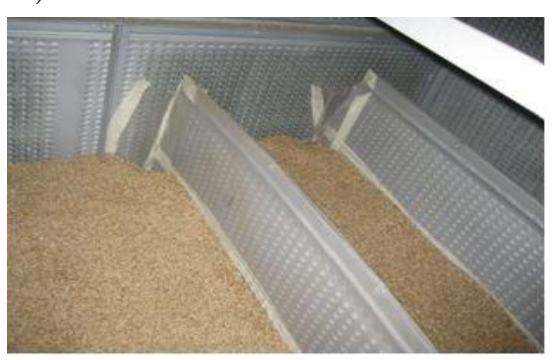

c)

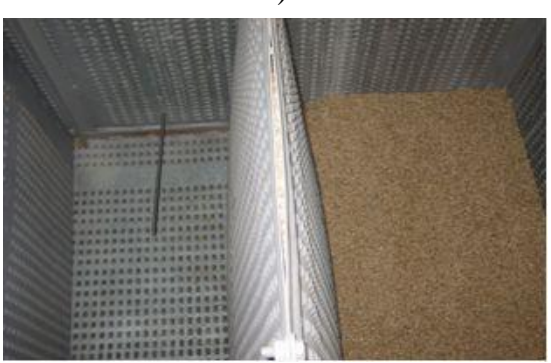

d)

Figure 1. Grain storage with built-in solar drying system:

$\mathrm{a}$ - basic diagram; $\mathrm{b}$ - general view; $\mathrm{c}$ - the grain storage sections; $\mathrm{d}$ - section view with temperature sensor.

1 - vertical solar collector; 2 - translucent cover; 3 - light-absorbing surface;

4 - drying chamber; 5 - perforated decking; 6 - dried grain; 7 - exhaust pipe;

8 - deflector; 9 - gravel accumulator; 10 - perforated air-distribution channels; 11 - openings in grain storage wall; 12 - longitudinal partition; 13 - transversal partition; 14 - door; 15 - shutters; 16 - roof canopy 
The drying process during storage proceeds as follows. Due to the draft arising in the exhaust pipe 7, the ambient air enters through the input slot under the canopy 16 into the solar collector 1, where it is heated and through openings 11 is distributed in the space under the floor, simultaneously heating the gravel accumulator 9. Perforated decking 5 and air distribution channels 10 evenly distribute heated air in the mass of dried grain 6 . The humidified air after passing through the grain layer is removed through the exhaust pipe 7 and deflector 8 . At night time drying continues due to the heat given by the gravel accumulator. To regulate the air exchange depending on the environmental parameters and the condition of the grain mass, dampers 15 are used.

Drum solar dryer (fig. 2) provides, if necessary, drying of individual grain batches, both when the grain comes from the field and during its storage [13].
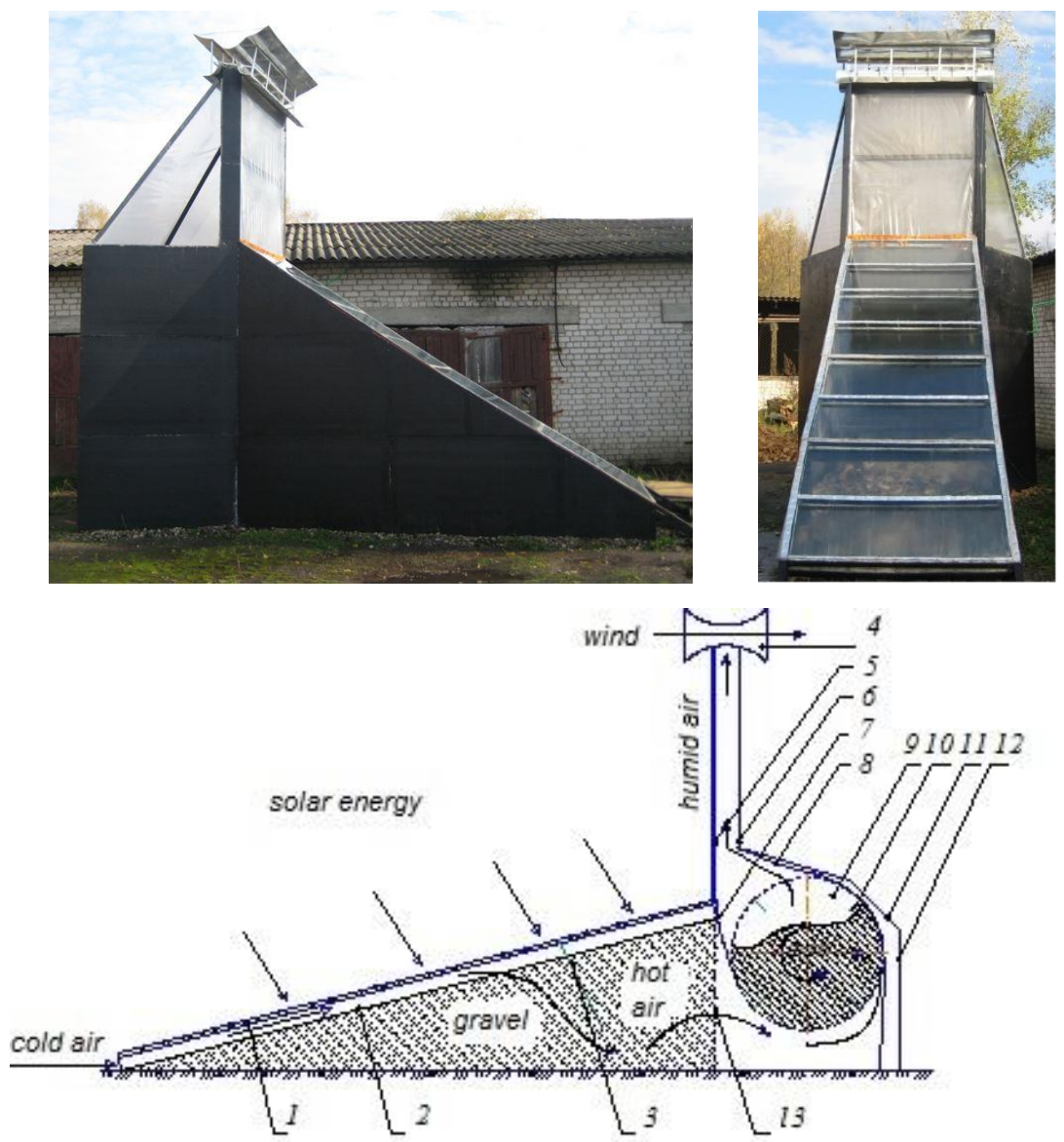

Figure 2. General view and scheme of drum solar dryer:

1 - inlet collector with double transparent coating; 2 - gravel heat accumulator; 3 - partition; 4 exhaust pipe deflector; 5 - double transparent coating; 6 - rear heat-receiving wall; 7 - front rubber apron; 8 - rear rubber apron; 9 - drying drum;

10 - shovels; 11 - top cover; 12 - bottom cover; 13 - grid 
The solar dryer consists of the inlet collector with double transparent coating 1, gravel heat accumulator 2 with the volume of $0.5-0.75 \mathrm{~m}^{3}$ per $1 \mathrm{~m}^{2}$ of the collector area. The heat accumulator has partition 3, which serves to organize the passage of air through the gravel. The upper blackened layer of gravel serves as a heat-receiving surface. To strengthen the draft there is a deflector 4 of the exhaust pipe, which is the vertical solar collector formed by transparent coating 5 and the rear heat-receiving wall 6 .

Rubber aprons 7 and 8 are installed in the drying chamber to organize the flow of heated air. Drying drum 9 is installed in supports and has covers for loading and unloading of grain.

The drum has blades 10, which are used to mix the drying product. To load the drum, the drying chamber has opening covers 11 and 12. The drum is driven in rotation by a motor through the reducer. The chamber is separated from the collector by grid 13 .

The solar dryer works in the following way. The drum is filled with grains to $3 / 4$ of its volume. The air from outside enters the drying chamber, passing through the gap between the transparent covering of the inlet collector and the surface of the gravel, enveloping the partition and being heated.

The excess heat is absorbed by the gravel. The air enters the chamber through the grid 13. Aprons 7 and 8 slide over the surface of the drum and organize the air flow as shown in fig. 2 - from the bottom of the drum through it and then up into the exhaust collector, where it is additionally heated and goes upwards, forming a draft. If there is wind, the draft is increased by the deflector, which also prevents water from entering the drying chamber when it rains.

A disadvantage of a solar dryer is the lack of mechanization means of loading and unloading of dried material. This disadvantage can be eliminated by a designed solar dryer designed in different way (fig. 3), [14].

Mechanized solar dryer-storage unit works as follows. The material to be dried by means of the loading conveyor 9 is fed into the drying chamber 11 . Guide tray 10 provides the material to the gap between the ends of perforated air channels 12 and the walls of the exhaust pipe 6 . This provides consistent uniform distribution of material in the drying chamber on the surfaces of the perforated air distribution channels 12 . In this case the sluice valves 14 are in a closed state, preventing the flow of material from the drying chamber 11 into the discharge channels 13 .

Under the influence of solar energy, the incoming atmospheric air (drying agent), consistently passes through the retractable film solar collector 1 with blackened coating and inclined solar collector 2 with translucent protection and is heated. At the same time the water in the water heat accumulator 3 is heated. Then the drying agent streams through the main air channel 4 and discharge channels 13 into the perforated air distribution channels 12 with open shutters 14, penetrates into the layers of the dried material, moistens and is exhausted through the exhaust pipe 6 into the atmosphere.

The shutters 14 allow closing the supply of the drying agent in the corresponding perforated air distribution channels 12 when the drying chamber 11 is not completely filled. This prevents the free outlet of the drying agent into the exhaust pipe 6 , bypassing the material layer.

At insufficient draft in the exhaust pipe 6 the exhaust fan 8 is switched on. Increasing the heating of the drying agent and accordingly the drying speed is provided by increasing the area of the heat-receiving surface with horizontal extending solar collector 1 as well as by regulating the amount of water in the water heat accumulator 3 . 
At reduction of water volume in the accumulator more solar energy goes on heating of the drying agent that increases speed of drying and vice versa. The maximum volume of water in the water heat accumulator is required to ensure drying of the material at night. The water heat accumulator 3 is filled via the expansion tank 5 and emptied via the drain cock 20 .
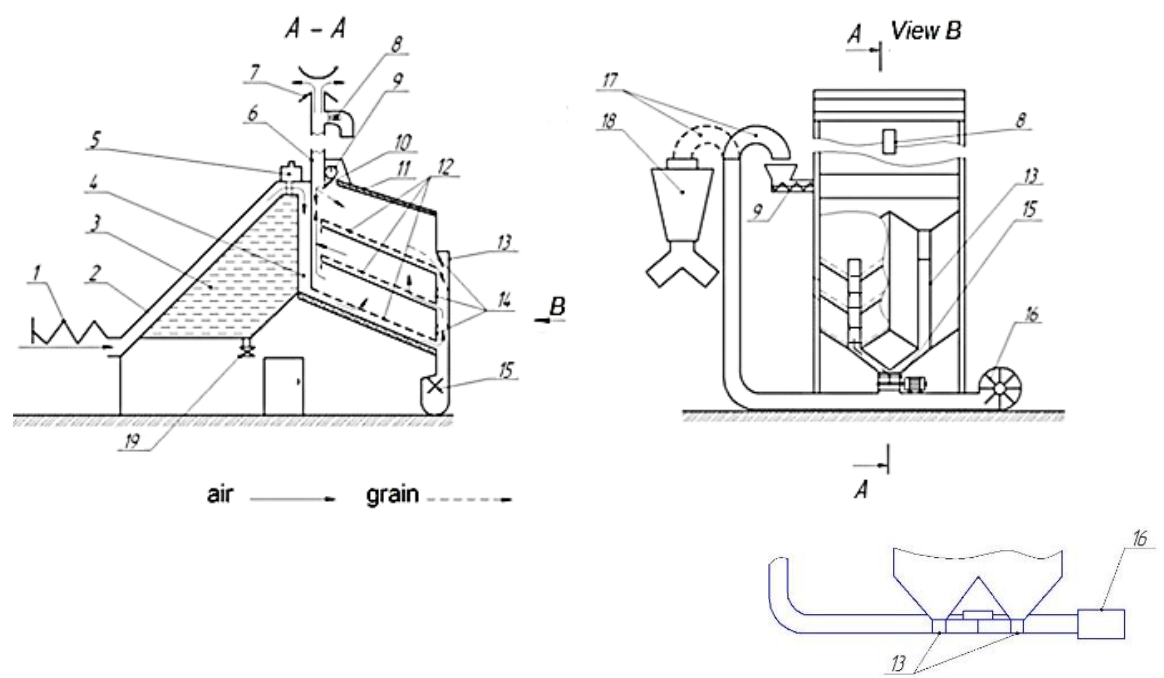

Figure 3. Solar dryer-grain storage:

1, 2 - sliding film and inclined solar collectors; 3 - water heat accumulator; 4 - main air channel; 5 - expander tank; 6 - exhaust pipe; 7 - deflector;

8 - exhaust fan; 9 - loading auger conveyor-distributor; 10 - guide channel;

11 - drying chamber; 12 - perforated air distributing channels; 13 - discharge channels; 14 shutters; 15 - sluice valve; 16 - pneumatic conveyor; 17 - rotary deflector; 18 - cyclone; 19 drain cock

To discharge the dried material, the sluice valves 14 are opened. The material under the gravity is poured into the discharge channels 13 and further through the sluice gate 15 into the pneumatic conveyor 16 . The rotary deflector 17 directs the material either back to the loading auger conveyor 9 for material recirculation or to the unloading cyclone 18 and further to processing or permanent storage.

\section{RESULTS AND DISCUSSION}

The drum solar dryer was tested for drying wheat, rye, barley, oats, buckwheat, grain legumes, as well as herbs, mushrooms, fruits and marshmallows. Tests of solar dryers and grain store showed that the presence of a permanent natural draught at the expense of the solar collector exhaust pipe provides preservation of wet grain even under adverse weather conditions. In the absence of the sun the solar dryers operate for some time due to the heat stored in the gravel or water accumulator.

The optimum capacity of the gravel accumulator is $0.5-0.75 \mathrm{~m}^{3}$ per $1 \mathrm{~m}^{2}$ of solar collector area. Duration of drying depends on humidity of grain and solar activity. 
On a bright sunny summer day, $1 \mathrm{~m}^{2}$ of the collector can give up to $1 \mathrm{~kW}$ of heat output. During short summer rains, the grain in the solar dryer is sheltered from the rain, and drying continues due to the heat stored in the accumulator. Heating temperature of the drying agent does not exceed $70{ }^{\circ} \mathrm{C}$, and the temperature of grain heating does not exceed $40{ }^{\circ} \mathrm{C}$, which corresponds to the drying mode of seed grain.

The drum dryer provides guaranteed drying of grain batch for 6-7 hours of day time and grain batch for the night time. Specific load is up to $100 \mathrm{~kg}$ of grain per square meter area of the horizontal solar collector. In this case drying of grain batch with different humidity is provided. It also should be noted that in two hours after drying some increase in humidity of the grain is not observed, in contrast to the floor dryer and drum dryer with electric air heating.

Improving the efficiency of solar dryer drum as compared to existing models, provided by the optimal organization of air movement in the dryer through the lower inclined solar collector and gravel heat accumulator, the presence of the upper vertical solar collector in the form of an exhaust pipe, as well as deflector, significantly increasing the draft in the dryer.

The design of the dryer provides grain drying also at night time by accumulating heat energy during the day in the gravel accumulator and releasing it at night time. Gravel accumulator and increased draft in the exhaust pipe prevent the formation of condensation in the dryer and increase the humidity of grain during the rainy season. This makes it possible to store moist grain in the dryer during such a period without the danger of its self-heating. An important advantage of mechanized solar dryer-grain storage is the possibility of recirculation of grain, which accelerates drying and provides its uniformity for the entire grain batch.

\section{CONCLUSIONS}

With large volumes of grain production, it is advisable to dry wet seeds by a combined method in two stages, involving preliminary removal of moisture in solar dryers, and then bringing the grain to the required conditions using high-temperature dryers. Division of the drying process into two stages will reduce moisture removal in high-temperature dryers, which will increase their carrying capacity by 1.5-2.0 times, and will significantly reduce energy costs for drying of grain.

When using only solar dryers, the total volume of drying drums or chambers should be equal to half of the daily volume of incoming wet grain. Additional drying of grain in the process of its storage in the solar dryer-granary is also possible.

In case of serial production of drying chambers in the form of separate modules it is possible to provide the required productivity of the offered drying complex.

The most rational use of solar dryers is for drying of small seed grain batches, seeds of vegetable and herbaceous crops, as well as for heat treatment of seeds before sowing. 


\title{
REFERENCES
}

[1] Kupreenko, A., Isaev, Kh., Chenin, A. 2020. Application of solar grain dryers in conditions of Bryansk region: theory and results: monograph. Bryansk: Ed. Bryansk State Agrarian University.

[2] Severnev, M.M. 1992. Energy-saving technologies in agricultural production. Moscow, Kolos.

[3] Kharchenko, N.V. 1991. Individual Solar Installations. Moscow, Energoizdat.

[4] Bezrukikh, P.P. 2005. Renewable energy: strategy, resources, technology. Moscow: State Scientific Institution All-Russian Research Institute of Electrification of Agriculture.

[5] Nwakuba, N. 2019. Optimisation of energy consumption of a solar-electric dryer during hot air drying of tomato slices. Journal of Agricultural Engineering, vol. 50, No 3, pp. 150-158.

[6] Balasuadhakar, A., Atenafu, A., Fisseha, T., Bino, B. 2016. A Review on Passive Solar Dryers for Agricultural Products. International Journal for Innovative Research in Science \& Technology, vol. 3, Issue 01/013, pp. 64-70.

[7] El-Sebaii, A., Shalaby, S. 2012. Solar drying of agricultural products: A review. Renewable and Sustainable Energy Reviews, vol. 16, Issue 1, pp. 37-43.

[8] Tiwari, A. 2016. A Review on Solar Drying of Agricultural Produce. Journal of Food Processing and Technology, vol. 7:623.

[9] Kupreenko, A., Isaev, Kh., Baydakov, E. 2011. Результаты испытания солнечного коллектора зернохранилища со встроенной гелиосушильной системой. Bulletin of the Bryansk State Agricultural Academy, vol. 1, pp. 55-62.

[10] Kupreenko A., Isaev Kh., Baidakov E. 2012. Эффективность использования барабанной гелиосушилки зерна. Bulletin of V.P. Goryachkin Moscow State Agrarian University, vol. 3, pp. 33-35.

[11] Baidakov, E., Kupreenko, A., Isaev, Kh., Chenin, А. 2014. Разработка барабанной гелиосушилки зерна и обоснование ее конструктивно-технологических параметров. Technology of wheeled and tracked machines. vol. 6, pp. 10-16.

[12] Kupreenko, A., Tikhiy, V., Isayev, Kh., Baydakov, E. 2010. Useful model patent No. 96225, RU. Solar dryer.

[13] Kupreenko, A., Tikhiy, V., Isayev, Kh., Baydakov, E. 2008. Useful model patent № 71744, RU. Solar dryer.

[14] Chashchinov, V., Kupreenko, A., Isaev, Kh., Baydakov, E., Chenin, A. 2015. Useful model patent № 159524, RU. Solar dryer.

\section{UPOTREBA SOLARNIH POSTROJENJA ZA SUŠENJE SEMENA USEVA}

\author{
Aleksey Kupreenko ${ }^{1}$, Khafiz Isaev ${ }^{1}$, Yury Kuznetsov ${ }^{2}$, Stanislav Mikhailichenko ${ }^{1}$, \\ Igor Kravchenko ${ }^{3}$, Larisa Kalashnikova ${ }^{4}$ \\ ${ }^{1}$ Bryansk State Agrarian University, Bryansk, Russia \\ ${ }^{2}$ Orel State Agrarian University, Orel, Russia \\ ${ }^{3}$ Russian State Agrarian University-Moscow Timiryazev Agricultural \\ Academy, Moscow, Russia \\ ${ }^{4}$ Orel State University, Orel, Russia
}

Sažetak: Predložena konstrukcija postrojenja za sušenje zrna žitarica je bazirana na korišćenju solarne energije, koja uključuje skladište žitarica sa ugrađenim solarnim sistemom za sušenje i bubanj solarnu sušaru za zrna žita. 
Opisana je konstrukcija i princip rada postrojenja za sušenje zrna. Osnova svakog od solarnih sistema za sušenje je prisustvo dva solarna kolektora. Jedan obezbeđuje zagrevanje vazduha-medijuma za sušenje na ulazu u komoru za sušenje, a drugi zagrevanje korišćenog vazduha-medijuma za sušenje u izduvnoj komori, cevi za povećanje protoka, i zbog toga, intenziviranje sušenja zrna.

Dostupnost akumulatora toplote (voda ili šljunak) omogućava izvođenje procesa sušenja ili skladištenja zrna, noću i pod nepovoljnim vremenskim uslovima bez rizika samozagrevanja. Optimalni kapacitet akumulatora (šljunak) je $0,5-0,75 \mathrm{~m}^{3} / \mathrm{m}^{2}$ površine solarnog kolektora. Solarna sušara sa bubnjem obezbeđuje garantovano sušenje šarže zrna tokom 6 do 7 sati dnevno i šarže zrna noću.

Utvrđeno je da je optimalna debljina sloja zrna u procesu sušenja 50 do $70 \mathrm{~cm}$ i specifično opterećenje do $100 \mathrm{~kg} / \mathrm{m}^{2}$ horizontalne površine solarnog kolektora.

Ključne reči: Solarno postrojenje, vlaga, solarna sušara, komora za sušenje, razmena vazduha, skladištenje zrna

Prijavljen:

Submitted: 15.04.2021.

Ispravljen:

Revised: 22.05.2021.

Prihvaćen:

Accepted: 01.06.2021. 